\title{
PENGARUH PELATIHAN, MOTIVASI KERJA DAN KOMPETENSI TERHADAP KINERJA PERSONEL DI MAKOSEK HANUDNAS I.
}

\author{
Ahmad Badawi Saluy \\ Program Pascasarjana Magister Manajemen Universitas Mercu Buana \\ badawisaluy@yahoo.co.id \\ Tersia Musanti \\ Program Pascasarjana Magister Manajemen Universitas Mercu Buana \\ tersia_musanti@yahoo.com \\ Bambang Mulyana \\ Program Pascasarjana Magister Manajemen Universitas Mercu Buana \\ bambang_0406@yahoo.co.id
}

\begin{abstract}
Abstrak.
Penelitian ini dilakukan untuk mengetahui apakah ada pengaruh antara pelatihan terhadap kinerja personel, apakah ada pengaruh motivasi kerja terhadap kinerja personel, apakah ada pengaruh kompetensi terhadap kinerja personel dan apakah ada pengaruh pelatihan, motivasi kerja dan kompetensi secara bersama-sama terhadap kinerja personel. Adapun yang menjadi objek penelitan pada penelitian ini adalah para Personel Militer /TNI di Makosek Hanudnas I yang berjumlah 184 orang. Variabel yang digunakan dalam penelitian ini adalah pelatihan, motivasi kerja, kompetensi dan kinerja personel, variabel pelatihan dinotasikan sebagai variabel $\mathrm{X}_{1}$, variabel motivasi kerja dinotasikan sebagai variabel $X_{2}$, variabel kompetensi dinotasikan sebagai variabel $X_{3}$, sedangkan variabel kinerja personel dinotasikan sebagai variabel Y. Data yang diperoleh dianalisis dengan menggunakan regresi linier berganda. Hasil penelitian menunjukkan bahwa terdapat pengaruh antara pelatihan terhadap kinerja personel, terdapat pengaruh antara motivasi kerja terhadap kinerja personel, terdapat pengaruh antara Kompetensi terhadap kinerja personel dan terdapat pengaruh antara pelatihan, motivasi kerja dan kompetensi secara bersama-sama terhadap kinerja Personel Militer/TNI di Makosek Hanudnas I.
\end{abstract}

Kata Kunci: Pelatihan, Motivasi kerja, Kompetensi, Kinerja personel

\begin{abstract}
.
This research is conducted to find out the influence of training to personnel performance, the influence of work motivation to personnel performance, the influence of competence to personnel performance and the influence of training, work motivation and competence altogether to personnel performance. The subjects of this research are 184 employees of Makosek Hanudnas I.Variable used in this research are training, work motivation, competence and employees performance. Training is noted as X1 variable; work motivation as X2 variable; and competence as X3 variable, while employees performance is noted as $Y$ variable. The data obtained from the research was analysed using multiple linier regression. The result showed that there are influences of training to personnel performance, influences of work motivation to personnel performance, influences of competence to personnel performance and influences of training, work motivation and competence altogether to personnel performance at Makosek Hanudnas I.
\end{abstract}

Keywords: training, work motivation, competence, personnel performance 


\section{PENDAHULUAN}

Personel militer/prajurit TNI

Makosekhanudnas I dituntut untuk memiliki kompetensi terhadap pemahaman dan penguasaan serta aplikasi prosedur operasional Sistem Pertahanan Udara yang menjadi tugas utama organisasi. Prosedur Operasional Sistem Pertahanan Udara perlu dimengerti, dipahami dan diaplikasikan dalam setiap pelaksanaan kegiatan formal sehingga mampu menghasilkan produktivitas atau kinerja yang tinggi, baik individu, kelompok/team work maupun kesatuan. Kualitas sumber daya manusia, baik personel militer/prajurit TNI Kosekhanudnas I memiliki variasi latar belakang pendidikan yang berimplikasi pada kinerja. Personel /prajurit TNI di lingkungan Makosekhanudnas I memiliki latar belakang pendidikan setingkat Paket, mempunyai golongan cukup tinggi akan tetapi latar belakang pendidikannya hanya setingkat SMU. Hal ini mengakibatkan tingkat kompetensi personel militer atau TNI di lingkungan Makosekhanudnas I tidak merata. Sementara itu, kemampuan dan keahlian personel militer/TNI Makosekhanudnas I sangat tergantung pada pelatihan Hanudnas yang disiapkan khusus untuk pelaksanaan tugas sebagai "Penjaga Langit". Keahlian, keterampilan serta penguasaan pengetahuan secara umum maupun khusus terkait Sistem Pertahanan Udara sebagai tugas pokok satuan hanya dapat diperoleh secara berjenjang dan berlanjut di pelatihan Hanudnas yang diselenggarakan oleh Pusdik Hanudnas. Akan tetapi menurut fakhrika (2014), tingkat pendidikan dan pelatihan tidak berpengaruh terhadap kompetensi.

Aspek tingkat kesadaran personel militer/prajurit TNI dalam melakukan pekerjaan di lingkungan Makosekhanudnas I, mengindikasikan bahwa tingkat motivasi personel militer/prajurit TNI dalam melakukan penyelesaian pekerjaan di Lingkungan Mako sekhanudnas I masih cukup rendah. Di sisi lainya, tugas dan tanggung jawab juga membutuhkan kemampuan dan keterampilan khusus tentang teknis dan taktis serta strategis, terutama berkaitan dengan pemahaman Sistem dan Prosedur Pertahanan Udara masih belum menunjukkan kinerja yang optimal. 
KAJIAN TEORI DAN PENGEMBANGAN

HIPOTESIS

Menurut Mulyasa (2007) Kompetensi merupakan komponen utama dari standar profesi di samping kode etik sebagai regulasi perilaku profesi yang ditetapkan prosedur dan sistem pengawasan tertentu. Kompetensi terkait erat dengan standar. Di mana seseorang disebut kompeten dalam bidangnya jika pengetahuan, ketrampilan dan sikapnya, serta hasil kerjanya sesuai standar (ukuran) yang ditetapkan dan atau diakui oleh lembaganya atau pemerintah.

Pelatihan, menurut Simanjuntak (2005) merupakan bagian dari investasi SDM (human investment) untuk meningkatkan kemampuan dan keterampilan kerja, dan dengan demikian meningkatkan kinerja pegawai. Sedangkan Rivai (2005), pelatihan secara singkat didefinisikan sebagai suatu kegiatan untuk meningkatkan kinerja saat ini dan kinerja di masa mendatang.

\section{Hipotesis}

Dari permasalahan yang telah diangkat dalam paragraf sebelumnya, maka hipotesis sebagai berikut:

H1: Ada pengaruh Pelatihan terhadap Kinerja personel Makosek Hanudnas I.
H2: Ada pengaruh Motivasi kerja terhadap Kinerja personel Makosek Hanudnas I.

H3: Ada pengaruh Kompetensi terhadap Kinerja personel Makosek Hanudnas I

H4: Ada pengaruh Pelatihan, Motivasi kerja dan Kompetensi secara simultan terhadap Kinerja personel Makosek Hanudnas I.

Penjabaran dari pemikiran bahwa terdapat tiga variabel bebas, yakni Pelatihan, Motivasi Kerja dan Kompetensi memiliki pengaruh terhadap Kinerja Personel Militer/TNI di Makosekhanudnas I yang merupakan variabel terikat dapat dipahami dengan mengadopsi konsep teori yang telah ada. Terkait konsep motivasi Suryabrata (2005) mengemukakan bahwa motivasi adalah kondisi psikologis seseorang yang mendorong seseorang untuk melakukan aktivitas-aktivitas tertentu guna mencapai suatu tujuan.

Beberapa Teori yang berkaitan dengan motivasi adalah Teori Kepuasan antara lain:

1. Teori Motivasi Klasik dari F.W.Taylor. Teori ini berpendapat bahwa manusia mau bekerja giat untuk dapat memenuhi kebutuhan fisik, berbentuk uang atau 
barang dari hasil pekerjaannya. Konsep

dasar teori ini adalah orang akan bekerja

giat bilamana ia mendapat imbalan

materi yang mempunyai kaitan dengan

tugas-tugasnya.

2. Teori Hierarki Kebutuhan (Need hierarchi) dari Abraham Maslow.

Maslow dalam Siagian, Sondang (2002)

menerangkan bahwa manusia

mempunyai sejumlah kebutuhan yang

dapat diklasifikasikan dalam tingkatan

atau hirarki (hirarchy of need) yaitu :

a. Kebutuhan Fisiologis. Kebutuhan yang harus dipuaskan untuk dapat tetap hidup dan sebagai kebutuhan dasar. Kebutuhan fisiologis meliputi kebutuhan makan, minum, seksual, kebutuhan perlindungan fisik, kebutuhan rumah dsb.

b. Kebutuhan Akan Rasa Aman. Kebutuhan akan rasa aman adalah kebutuhan akan terbebas dari segala bentuk ancaman. Kebutuhan ini meliputi kebutuhan merasa aman, kebutuhan perlindungan dari bahaya, pertentangan lingkungan hidup. Aman dan terlindungi dari kekhawatiran dan ketakutan adanya potensi ancaman.

c. Kebutuhan Sosial. Kebutuhan sosial merupakan kebutuhan untuk dapat diterima dalam komunitas. Kebutuhan ini meliputi kebutuhan untuk diterima teman atau kelompok pekerja dan masyarakat di lingkungannya, kebutuhan merasa memiliki, kebutuhan berafiliasi, berinteraksi. Kebutuhan sosial merupakan kebutuhan untuk menjadi bagian dari komunitas di lingkungannya.

d. Kebutuhan Akan Penghargaan. Kebutuhan akan penghargaan adalah kebutuhan akan pengakuan dan penghargaan diri dari karyawan dan masyarakat lingkungannya. Kebutuhan akan pengakuan dan penghargaan keberadaan diri atau eksistensi diri oleh pihak luar atau orang-orang di sekitarnya.

e. Kebutuhan Aktualisasi diri. Kebutuhan aktualisasi diri adalah kebutuhan akan aktualisasi diri dengan menggunakan kemampuan, 
keterampilan dan eksplorasi potensi diri secara optimal untuk mencapai prestasi kerja yang sangat memuaskan atau luar biasa.

Gambaran tentang teori motivasi menurut Abraham Maslow terdapat pada Gambar 1.

Sedangkan kompetensi merupakan seperangkat pengetahuan, keterampilan, dan sikap yang harus dimiliki, dihayati, dikuasai, dan diwujudkan oleh seseorang dalam melaksanakan tugas keprofesionalan tanpa meninggalkan aspek kemampuan kepribadian dan kemampuan sosial dalam melaksanakan tugas-tugasnya (Chapman, 2006). Olson dan Bolton (2005) mengilustrasikan cakupan konsep kompetensi dalam literatur organisasi yang diadaptasi dari Green (2005). Ditunjukkan bahwa kompetensi merujuk pada individu maupun organisasi.

Sebagai variabel terikat, kinerja menurut konsep menurut Flippo dalam Tika (2010) yang menjelaskan bahwa standar ukuran kinerja antara lain sebagai berikut:

1. Kualitas hasil kerja yang meliputi: (a) Ketepatan kerja dan waktu; (b) Tingkat kemampuan bekerja; (c) Kemampuan menganalisa data atau informasi baik yang bersifat untuk perbaikan maupun kearsipan.

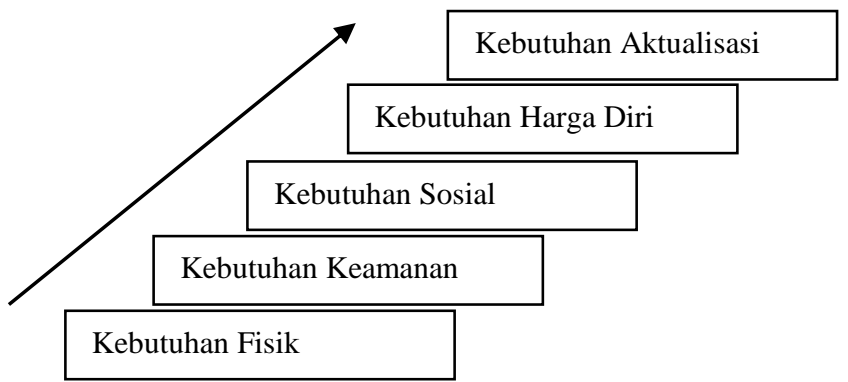

Gambar 1. Maslow's Need Hierarchy

2. Kuantitas hasil pekerjaan yang meliputi:

(a) Proses pekerjaan dan kondisi pekerja; (b) Jumlah dan jenis pemberian pelayanan dalam bekerja; (c) Waktu yang diperlukan dalam pelaksanaan pekerjaan; (d) Pekerjaan reguler dan jumlah pekerjaan tambahan yang diselesaikan.

Berakar dari konsep Kinerja tersebut, pemahaman tentang Kinerja yang dimiliki oleh personel militer/TNI di Makohanudnas I pada T.A 2014 sampai dengan T.A 2015 masih ditemukan adanya kelemahan, yaitu dari jumlah banyaknya hasil pekerjaan yang diberikan berupa produk staf yang merupakan bentuk hasil kerja satuan secara kolektif antar satuan-satuan kerja dalam organsasi MakosekHanudnas I. 
Tabel 1. Daftar Golongan Jabatan

Fungsional dan Tingkat Pelatihan

Hanudnas dalam Sruktur Organisasi Makohanudnas I

\begin{tabular}{|c|c|c|c|c|c|}
\hline No & 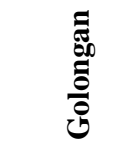 & 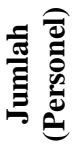 & 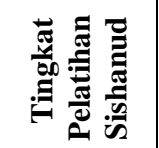 & 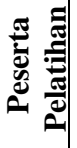 & 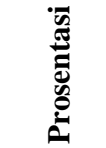 \\
\hline 1 & $\begin{array}{c}\text { Unsur } \\
\text { Pimpinan }\end{array}$ & 1 & Advance & 1 & $100 \%$ \\
\hline 2 & $\begin{array}{c}\text { Unsur } \\
\text { Pembantu } \\
\text { Pimpinan }\end{array}$ & 5 & $\begin{array}{l}\text { Advance } \\
\text { Middle } \\
\text { Elementary } \\
\text { Non Skill }\end{array}$ & 3 & $60 \%$ \\
\hline 3 & $\begin{array}{c}\text { Unsur } \\
\text { Pelayanan } \\
\text { dan } \\
\text { Pelaksana } \\
\end{array}$ & 178 & $\begin{array}{c}\text { Advance } \\
\text { Middle } \\
\text { Elementary } \\
\text { Non Skill } \\
\end{array}$ & $\begin{array}{c}1 \\
67 \\
30 \\
80 \\
\end{array}$ & $\begin{array}{c}0.56 \% \\
37.64 \% \\
16.85 \% \\
44.94 \% \\
\end{array}$ \\
\hline & TOTAL & 184 & & 184 & \\
\hline
\end{tabular}

Sumber: DSP Kosekhanudnas I Tri Wulan Tahun 2015

Motivasi kerja di lingkungan personel militer /TNI di Makosekhanudnas I dari aspek kesadaran personel, seperti pada Tabel 2.

Tabel 2 menggambarkan respon personel dalam pekerjaan yang menjadi tanggung jawabnya, yang mencapai $30 \%$ s.d $34 \%$ yang secara statistik menunjukkan lemahnya motivasi kerja personel militer/TNI.

Dari penelitian awal, ditemukan berbagai permasalahan yang menjadi kendala dalam pelaksanaan tugas dan kemungkinan adanya korelasi dari berbagai faktor terhadap kinerja personel.
Tabel 2. Tingkat Kesadaran pada personel TNI dalam Melakukan Penyelesaian Pekerjaan di Lingkungan Makosekhanudnas I

\begin{tabular}{cccc}
\hline NO & ALASAN & PERSONEL & KET \\
\hline 1 & $\begin{array}{c}\text { Pekerjaaan tersebut } \\
\text { membebani diri }\end{array}$ & 61 & $33, \%$ \\
2 & $\begin{array}{c}\text { Pekerjaan sebagai } \\
\text { keterpaksaan } \\
\text { Pekerjaan sebagai } \\
\text { bentuk rutinitas }\end{array}$ & 61 & $33 \%$ \\
\hline & Jumlah & $\mathbf{1 8 4}$ & $\mathbf{1 0 0 \%}$ \\
\hline Sumber : Survei Pra
\end{tabular}

Sumber : Survei Pra Kuesioner

\section{METODE RISET}

Penelitian ini merupakan penelitian eksplanatori yang bertujuan untuk menjelaskan hubungan kausal (pengaruh) dan menguji hipotesis. Penelitian ini bertujuan untuk mengetahui pengaruh Pelatihan, Motivasi kerja dan Kompetensi terhadap Kinerja personel dan pengaruh kompetensi terhadap Kinerja personel militer/TNI di Makosek Hanudnas I. Dari sudut metode pengumpulan data, penelitian ini adalah penelitian survei yang mengambil sampel untuk diteliti dan menggunakan kuesioner sebagai alat pengumpul data yang pokok. Berkaitan dengan metode analisisnya, penelitian ini adalah penelitian kuantitatif dengan menggunakan statistika sebagai alat analisis yang utama, dengan berbagai aspek sebagai populasi dan sampel penelitian. 


\section{Populasi dan Sampel Penelitian}

Populasi

Populasi pada penelitian ini adalah para personel militer/TNI Makosek Hanudnas I pada periode TW I TA 2015, yaitu sejumlah 184 orang.

Sampel

Teknik pengambilan sampel di dalam penelitian ini adalah Probability Sampling, dengan alasan Personel Militer/TNI Makosek Hanudnas I berjumlah 184 orang, maka pengumpulan data dilakukan terhadap populasi adalah Metode Sensus. (Sampling Sugiyono, 2011).

\section{Sumber Data dan Pengumpulan Data}

\section{Jenis dan Sumber Data}

Jenis dan sumber data pada penelitian ini adalah berbentuk data primer, di mana data penelitian ini diambil langsung dari lokasi penelitian yaitu melalui kuesioner yang disebarkan kepada semua responden yang dalam hal ini adalah para personel militer Makosek Hanudnas I. Data yang terkumpul kemudian diolah dan dianalisis dengan bantuan program software pengolahan data SPSS.

\section{Teknik Pengumpulan Data}

Teknik pengumpulan data yang digunakan dalam penelitian ini adalah pengisian kuesioner, studi dokumentasi dan wawancara.

\section{Dimensi Variabel Penelitian}

Penelitian ini juga menjelaskan tabel jawaban dari pertanyaan dimensi pada variabel-variabel, baik variabel dependen maupun independen, yaitu:

1. Variabel Pelatihan (X1) menggunakan beberapa dimensi dan indikator, yaitu:

a. Dimensi Materi Pelatihan, dengan Indikator: (1) Materi Pelatihan dirancang dengan baik; (2) Materi Pelatihan yang diadakan membahas tentang masalah yang sedang dihadapi atau sedang dibicarakan

b. Dimensi Metode Pelatihan, dengan Indikator: (1) Metode yang dipilih telah disesuaikan dengan jenis pelatihan yang akan dilaksanakan; (2) Metode pelatihan dapat mudah dipahami oleh peserta; (3) Para pelatih (trainer) merupakan orang yang berpengalaman dan ahli di bidangnya; (4) Para pelatih (trainer) dapat Menimbulkan dan 
meningkatkan perhatian para

personel kepada aspek tugas dan

tanggung jawab yang diemban.

c. Dimensi Sarana Pelatihan, dengan

indikator: (1) Tempat pelatihan

tertata dengan dengan baik; (2)

Sarana dan perlengkapan pelatihan

telah disediakan dengan lengkap.

d. Dimensi Peserta Latihan, dengan indikator: (1) Peserta pelatihan memusatkan perhatian terhadap masalah-masalah yang sedang ditangani di lapangan; (2) Peserta

Pelatihan Memberikan perhatian terhadap hal-hal yang menjadi tugas dan fungsinya sebagai seorang karyawan yang baik.

e. Dimensi Evaluasi Pelatihan, dengan Indikator: (1) Pelatihan dapat Meningkatkan partisipasi dalam volune pekerjaan; (2) Pelatihan dapat Membangkitkan minat dan rasa ingin tahu karyawan terhadap sesuatu.

2. Variabel Motivasi kerja (X2) menggunakan beberapa dimensi dan indikator, yaitu: a. Dimensi Faktor Instrinsik (Faktor Internal), dengan Indikator: (1) Insentif; (2) Penghargaan atas prestasi; (3) Gaji.

b. Dimensi Faktor Ekstrinsik (Faktor Eksternal), dengan Indikator: (1) Hubungan dengan rekan kerja; (2) Lingkungan kerja; (3) Perlakuan adil.

c. Dimensi Pengetahuan (Knowledge), dengan indikator: (1) Memiliki pengetahuan dalam hal pelayanan yang baik dalam bidang pekerjaan yang dilakukan; Memiliki pengetahuan yang baik terhadap tugas dan tanggung jawab.

\section{d. Dimensi Pemahaman}

(Understanding), dengan indikator memahami teori yang berkaitan dengan pekerjaan dengan baik.

3. Variabel Kompetensi (X3) menggunakan beberapa dimensi dan indikator, yaitu:

a. Dimensi Kemampuan atau Ketrampilan (Skill), dengan Indikator: (1) Mampu memecahkan masalah yang terjadi dalam pekerjaan; (2) Memiliki 
kemampuan berkomunikasi secara

baik dengan rekan kerja; (3)

Memiliki kemampuan

berkomunikasi secara baik dengan

rekan kerja.

b. Dimensi Nilai (Value) dengan indikator, yaitu: (1) Dapat berpikir kreatif dalam melaksanakkan pekerjaan; (2) Dapat memberikan ide yang baik dalam bekerja.

c. Dimensi Sikap (Attitude), dengan indikator, yaitu: (1) Mematuhi norma-norma sosial dalam melaksanakan pekerjaan; (2) Melaksanakan pekerjaan tepat waktu.

d. Dimensi Minat (Interest), dengan indikator, yaitu: (1) Memiliki minat terhadap hal-hal baru; (2) Berminat menyelesaikan setiap masalah yang rumit sekalipun.

4. Variabel Kinerja Personel (Y) menggunakan beberapa dimensi dan indikator, yaitu:

a. Dimensi Kuantitas hasil pekerjaan, dengan indikator: (1) Jumlah tugas sesuai dengan target kerja; b. Dimensi Kualitas pekerjaan, dengan indikator: (1) Memahami yang menjadi tugasnya; (2) Hasil kerja yang sesuai rencana.

c. Dimensi Pemanfaatan Waktu, dengan indikator: (1) Pelaksanaan tugas sesuai jadwal; (2) Mematuhi jadwal yang sudah dibuat.

d. Kehadiran, dengan indikator: (1) Hadir tepat waktu; (2)Kehadiran absensi.

e. Kerjasama, dengan indikator: (1) Mampu bekerjasama dengan atasan; (2) Mampu bekerjasama dengan rekan kerja.

Dalam penelitian ini telah dilaksanakan pengujian dari hasil pengolahan data sehingga pada akhirnya memberikan jawaban kebenaran bagi hipotesa yang dipilih.

\section{Uji Partial}

Uji Partial digunakan untuk menguji kemaknaan koefisien partial. Apabila $t_{\text {hitung }} \geq$ $\mathrm{t}_{\text {tabel }}$ maka Ho ditolak. Sebaliknya apabila thitung $\leq$ ttabel maka Ho diterima. 
Uji F (Uji Signifikan Simultan) Populasi

\section{Dan Sampel}

Populasi pada penelitian ini adalah para personel militer/TNI Makosek Hanudnas I yang berjumlah 184 orang. Teknik pengambilan sampel di dalam penelitian ini adalah Probability Sampling, dengan alasan personel Makosek Hanudnas I yang hanya berjumlah 184 orang, maka pengumpulan data dilakukan terhadap populasi atau metode sensus.

\section{Uji Validitas}

Uji Validitas ini membandingkan nilai masing-masing item pertanyaan dengan nilai total. Apabila besarnya nilai total koefisien item pertanyaan masing-masing variabel melebihi nilai signifikan maka pertanyaan tersebut tidak valid. Nilai $\mathrm{r}$ apabila valid atau tidak didapat dengan cara membandingkan $\mathrm{r}$ hitung (nilai korelatif/nilai Produtc Mament) dengan $r$ tabel. Apabila nilai $r$ hitung lebih besar dari nilai $r$ tabel dan nilai $r$ positif signifikan, maka butir pertanyaan tersebut dikatakan "Valid" (Ghozali, 2011).

\section{Uji Reliabilitas Data}

Uji Reliabilitas dilakukan dengan menggunakan Cronbach Alpha $(\alpha)$. Suatu variabel dikatakan reliabel jika memberikan nilai alpha $(\alpha)>0,60$ (Nunnally dalam Ghozali, 2011).

\section{Uji Asumsi Klasik}

Dalam perhitungan regresi, disyaratkan data yang dianalisis memenuhi beberapa asumsi klasik yaitu data berdistribusi normal (normalitas data), tidak terjadi korelasi kuat antar variabel (multikolinieritas), dan heteroskedastitas, yaitu jika varians dari residual suatu pengamatan ke pengamatan lain tetap. Pengujian data dalam penelitian ini dikenal dengan pengujian asumsi klasik, meliputi Uji Normalitas data, Uji Multikolinieritas, dan Uji Heteroskedastitas.

\section{Analisis Data}

Metode analisis data yang digunakan dalam penelitian ini meliputi analisis deskriptif dan rancangan uji hipotesis yang meliputi regresi linear sederhana dan regresi linear berganda, Uji t/uji signifikan parsial, uji F/uji signifikan simultan, pengujian koefisien determinasi $\left(\mathrm{R}^{2}\right)$ dan analisis korelasi.

\section{Analisis Deskriptif}

Analisa deskriptif, nilai yang diperoleh bisa diwakili mean (rata-rata), median, modus, tabel frekuensi dan berbagai diagram. 


\section{Pengujian Hipotesis}

Pengujian Hipotesis merupakan proses bertahap dalam suatu penelitian, meliputi berbagai langkah-langkah metodis dan sistematis dengan melakukan kegiatankegiatan ilmiah melalui pengolahan data dalam rumus-rumus tertentu.

\section{Analisa Regresi Linier}

Analisis Regresi Linier dipergunakan untuk mengetahui arah dan besar pengaruh dari variabel bebas yang jumlahnya lebih dari satu terhadap variabel tidak bebasnya. Analisis regresi linier adalah hubungan secara linier antara dua variabel independen (X) dengan variabel dependen (Y). Bentuk umum persamaan regresi berganda adalah sebagai berikut:

$$
\mathbf{Y}=\boldsymbol{\beta}_{0}+\boldsymbol{\beta}_{1} \mathbf{X}_{1}+\boldsymbol{\beta}_{2} \mathbf{X}_{2}+\boldsymbol{\beta}_{3} \mathbf{X}_{3}
$$

\section{Keterangan:}

$$
\begin{array}{ll}
\mathrm{Y} & =\text { Kinerja Personel } \\
\mathrm{X} 1 & =\text { Pelatihan } \\
\mathrm{X} 2 & =\text { Motivasi kerja } \\
\mathrm{X} 3 & =\text { Kompetensi } \\
\beta_{0} & =\text { Konstanta } \\
\beta_{1}-\beta_{3} & =\text { Koefisien regresi dari } \\
& \text { variabel bebas }(\mathrm{X} 1-\mathrm{X} 3)
\end{array}
$$

\section{Uji t (Uji Signifikansi Parsial)}

Uji simultan dilakukan untuk mengetahui apakah semua variable independen mempunyai pengaruh secara bersamaan terhadap variabel dependen. Untuk membuktikan kebenaran hipotesis, digunakan uji $\mathrm{F}$ dengan cara membandingkan nilai $\mathrm{F}_{\text {hitung }}$ dengan $F_{\text {tabel. }}$ Apabila $F_{\text {hitung }} \geq F_{\text {tabel }}$ maka Ho ditolak dan menerima Ha. Artinya bahwa variabel independen berpengaruh terhadap variabel dependen.

\section{Uji Koefisien Determinasi $\mathbf{R}^{2}$}

Koefisien determinasi (Adjusted $R$ Square) digunakan untuk melihat kemampuan variabel bebas dalam menerangkan variabel terikat dan proporsi variasi dari variabel terikat yang diterangkan oleh variasi dari variabelvariabel bebasnya. Jika R2 yang diperoleh dari hasil perhitungan menunjukkan semakin besar (mendekati satu), maka dapat dikatakan bahwa sumbangan dari variabel bebas terhadap variasi variabel terikat semakin besar. Hal ini berarti model yang digunakan semakin besar untuk menerangkan variabel terikatnya. Besarnya koefisien determinasi (R2) dapat dicari dengan rumus:

$$
\mathbf{R}^{2}=\frac{\sum y^{\wedge}}{\sum y^{2}}
$$


Dari koefisien determinasi dapat dketahui berapa besar kontribusi variabel independen terhadap variabel dependen.

\section{HASIL PENELITIAN DAN}

\section{PEMBAHASAN}

\section{Analisis Deskriptif Variabel}

Statistik deskriptif digunakan untuk menafsirkan besarnya rata-rata, dan standar deviasi dari Pelatihan, Motivasi kerja, Kompetensi dan Kinerja Personel di Makosek Hanudnas I. Hasil statistik yang didapat dalam penelitian ini dapat dijelaskan dari instrumen yang disampaikan kepada 184 orang responden sebagai uji coba. Jawaban responden menghasilkan tampilan bervariasi sesuai latar belakang, yang didasari dari tingkat pendidikan dan pengalaman kerja selama mejadi personel Makosek Hanudnas I. Seluruh jawaban yang diperoleh antara lain untuk menilai tingkat persepsi responden terhadap kondisi riil status, peran dan jabatan masing-masing dalam organisasi yaitu Makosek Hanudnas I yang tertuang dalam butir-butir perrtanyaan untuk mewakili dimensi-dimensi variabel penelitian.
Tabel 3. Deskripsi Jawaban Responden

\begin{tabular}{|c|c|c|c|c|c|}
\hline \multicolumn{6}{|c|}{ Descriptive Statistics } \\
\hline & $\mathbf{N}$ & $\dot{\Xi}$ & $\stackrel{\dot{x}}{\dot{x}}$ & $\stackrel{\Xi}{\mathbb{E}}$ & $\begin{array}{l}\text { Std. } \\
\text { Deviati } \\
\text { on }\end{array}$ \\
\hline Pelatihan & $\begin{array}{l}18 \\
4\end{array}$ & 2.83 & \begin{tabular}{l|}
5.0 \\
0
\end{tabular} & $\begin{array}{l}3.97 \\
69\end{array}$ & .37996 \\
\hline Materi pelatihan & $\begin{array}{l}18 \\
4\end{array}$ & 2 & 5 & 3.92 & .633 \\
\hline Metode pelatihan & $\begin{array}{l}18 \\
4\end{array}$ & 2 & 5 & 3.74 & .717 \\
\hline $\begin{array}{l}\text { Instruktur } \\
\text { Pelatihan }\end{array}$ & $\begin{array}{l}18 \\
4\end{array}$ & 2 & 5 & 3.84 & .630 \\
\hline Sarana Pelatihan & $\begin{array}{l}18 \\
4\end{array}$ & 3 & 5 & 3.98 & .592 \\
\hline Peserta Pelatihan & $\begin{array}{l}18 \\
4\end{array}$ & 3 & 5 & 4.06 & .587 \\
\hline Evaluasi Pelatihan & $\begin{array}{l}18 \\
4\end{array}$ & 3 & 5 & 4.33 & .532 \\
\hline Motivasi kerja & $\begin{array}{l}18 \\
4\end{array}$ & 2.90 & $\begin{array}{l}5.0 \\
0\end{array}$ & $\begin{array}{l}3.94 \\
78\end{array}$ & .38538 \\
\hline Faktor Instrinsik & $\begin{array}{l}18 \\
4\end{array}$ & 2 & 5 & 3.79 & .639 \\
\hline Faktor Ekstrinsik & $\begin{array}{l}18 \\
4\end{array}$ & 3 & 5 & 4.17 & .562 \\
\hline Kompetensi & $\begin{array}{l}18 \\
4\end{array}$ & 3.25 & \begin{tabular}{l|}
5.0 \\
0
\end{tabular} & $\begin{array}{l}4.21 \\
71\end{array}$ & .33705 \\
\hline $\begin{array}{l}\text { Pengetahuan } \\
\text { (Knowledge) }\end{array}$ & $\begin{array}{l}18 \\
4\end{array}$ & 3 & 5 & 4.49 & .573 \\
\hline $\begin{array}{l}\text { Pemahaman } \\
\text { (Understanding) }\end{array}$ & $\begin{array}{l}18 \\
4\end{array}$ & 3 & 5 & 4.51 & .572 \\
\hline $\begin{array}{l}\text { Kemampuan/Ketra } \\
\text { mpilan (Skill) }\end{array}$ & $\begin{array}{l}18 \\
4\end{array}$ & 2 & 5 & 4.28 & .648 \\
\hline Nilai (Value) & $\begin{array}{l}18 \\
4\end{array}$ & 3 & 5 & 4.34 & .589 \\
\hline Sikap (Attitude) & $\begin{array}{l}18 \\
4\end{array}$ & 3 & 5 & 4.27 & .591 \\
\hline Minat (Interest) & $\begin{array}{l}18 \\
4\end{array}$ & 1 & 5 & 4.50 & .618 \\
\hline Kinerja Pegawai & $\begin{array}{l}18 \\
4\end{array}$ & 3.10 & \begin{tabular}{|l|}
5.0 \\
0
\end{tabular} & $\begin{array}{l}4.33 \\
15\end{array}$ & .40433 \\
\hline $\begin{array}{l}\text { Kuantitas hasil } \\
\text { pekerjaan }\end{array}$ & $\begin{array}{l}18 \\
4\end{array}$ & 3 & 5 & 4.58 & .557 \\
\hline Kualitas pekerjaan & $\begin{array}{l}18 \\
4\end{array}$ & 1 & 5 & 4.34 & .649 \\
\hline $\begin{array}{l}\text { Pemanfaatan } \\
\text { Waktu }\end{array}$ & $\begin{array}{l}18 \\
4\end{array}$ & 2 & 5 & 4.26 & .766 \\
\hline Kehadiran & $\begin{array}{l}18 \\
4\end{array}$ & 3 & 5 & 4.64 & .536 \\
\hline Kerjasama & $\begin{array}{l}18 \\
4\end{array}$ & 2 & 5 & 4.54 & .608 \\
\hline Valid N (listwise) & $\begin{array}{l}18 \\
4\end{array}$ & & & & \\
\hline
\end{tabular}

Sumber : Pengolahan data (2016) 
Tabel 3 menunjukkan bahwa sebagian besar responden memberikan tanggapan setuju terhadap pertanyaan-pertanyaan mengenai variabel pelatihan sebagaimana yang dirasakan oleh diri responden diikuti oleh jawaban sangat setuju yang mempunyai total skor rata-rata 3.9769 dan nilai standar deviasi sebesar 0.37996. Nilai rata-rata jawaban terendah adalah 2.83 dan nilai rata-rata jawaban tertinggi adalah 5.00. Untuk dimensi pelatihan dengan nilai rata-rata paling tinggi adalah dimensi evaluasi pelatihan sebesar $\mathbf{4 . 3 3}$ dan dimensi pelatihan dengan nilai rata-rata paling rendah adalah metode pelatihan sebesar

3.74.

Untuk variabel motivasi kerja menunjukkan bahwa sebagian besar responden memberikan tanggapan setuju terhadap pertanyaan-pertanyaan mengenai variabel motivasi kerja sebagaimana yang dirasakan oleh diri responden diikuti oleh jawaban sangat setuju yang mempunyai skor rata-rata 4.2171 dan nilai standar deviasi sebesar 0.38538. Nilai rata-rata jawaban terendah adalah 2.90 dan nilai rata-rata jawaban tertinggi adalah 5.00. Untuk dimensi motivasi kerja dengan nilai rata-rata paling tinggi adalah dimensi faktor ekstrinsik sebesar 4.17 dan dimensi motivasi kerja dengan nilai ratarata paling rendah adalah faktor instrinsik sebesar 3.79.

Untuk variabel kompetensi menunjukkan bahwa sebagian besar responden memberikan tanggapan setuju terhadap pertanyaan-pertanyaan mengenai variabel kompetensi sebagaimana yang dirasakan oleh diri responden diikuti oleh jawaban sangat setuju yang mempunyai skor rata-rata 4.2171 dan nilai standar deviasi sebesar 0.33705 . Nilai rata-rata jawaban terrendah adalah 3.25 dan nilai rata-rata jawaban tertinggi adalah 5.00. Untuk dimensi kompetensi dengan nilai rata-rata paling tinggi adalah dimensi pemahaman (understanding) sebesar 4.51, adapun untuk dimensi kompetensi dengan nilai rata-rata paling rendah adalah dimensi sikap (attitude) sebesar 4.27.

Untuk variabel kinerja personel menunjukkan bahwa sebagian besar responden memberikan tanggapan setuju terhadap pertanyaan-pertanyaan mengenai variabel kinerja personel sebagaimana yang dirasakan oleh diri responden diikuti oleh jawaban sangat setuju yang mempunyai skor rata-rata 4.3315 dan nilai standar deviasi sebesar 0.40433. Nilai rata-rata jawaban terrendah 
adalah 3.10 dan nilai rata-rata jawaban tertinggi adalah 5.00. Untuk dimensi kinerja personel dengan nilai rata-rata paling tinggi adalah dimensi kehadiran sebesar 4.64, adapun untuk dimensi kinerja personel dengan nilai rata-rata paling rendah adalah pemanfaatan waktu sebesar 4.26.

\section{Uji Validitas}

Suatu instrumen dinyatakan valid apabila korelasi antara dua skor suatu butir dengan skor totalnya minimal sebesar 0,3 (Sugiyono, 2009) atau memiliki korelasi yang cukup kuat.

Adapun syarat validitas yaitu:

1. Jika $r_{\text {hasil }}$ positif, serta $r_{\text {hasil }}>0,30$ maka butir atau variabel tersebut valid.

2. Jika $r_{\text {hasil }}$ tidak positif, dan $r_{\text {hasil }}<0,30$ maka butir atau variabel tersebut tidak valid.

Terdapat 12 pernyataan variabel Pelatihan, semua pernyataan memiliki nilai $r$ $($ Pearson Correlation $)>0,30$, sehingga semua pernyataan dari variabel Pelatihan tidak perlu dikeluarkan karena statusnya valid. Terdapat 10 pernyataan variabel Motivasi kerja, semua pernyataan memiliki nilai $\mathrm{r}$ (Pearson Correlation) $>0,30, \quad$ sehingga semua pernyataan dari variabel Motivasi kerja tidak perlu dikeluarkan karena statusnya valid. Terdapat 12 pernyataan variabel Kompetensi, semua pernyataan memiliki nilai $\mathrm{r}$ (Pearson Correlation) $>0,30$, sehingga semua pernyataan dari variabel Kompetensi tidak perlu dikeluarkan karena statusnya valid. Terdapat 10 pernyataan variabel Kinerja Personel, semua pernyataan memiliki nilai $r$ $($ Pearson Correlation $)>0,30$, sehingga semua pernyataan dari variabel Kinerja Personel tidak perlu dikeluarkan karena statusnya valid.

\section{Uji Reliabilitas}

Pada program SPSS, pengujian ini dilakukan dengan metode Cronbach Alpha, di mana suatu kuesioner dikatakan reliabel jika nilai Cronbach Alpha lebih besar dari 0,60.

Pengujian Reabilitas dilakukan dengan hasil dalam Tabel 4, yaitu variabel dikatakan andal bila memiliki nilai Cronbach"s alpha dengan taraf nyata 5\%, kurang dari 0,6 dipertimbangkan buruk, di kisaran $\quad 0,7$ dipertimbangkan cukup, dan jika lebih besar dari 0,8 maka dipertimbangkan baik. Variabelvariabel yang digunakan dalam studi pendahuluan ini dinyatakan dapat diandalkan karena setiap faktor yang diteliti menunjukkan nilai Cronbach"s alpha lebih besar dari 0,6. 
Tabel 4. Hasil Uji Reliabilitas Pretest

\begin{tabular}{|c|c|c|c|}
\hline No & Variabel & $\begin{array}{c}\text { Cronbach's } \\
\text { Alpha }\end{array}$ & $\begin{array}{c}\text { Reliabili } \\
\text { tas }\end{array}$ \\
\hline 1 & Pelatihan & 0,741 & Reliabel \\
\hline 2 & Pelatihan & 0,624 & Reliabel \\
\hline 3 & Kompetensi & 0,665 & Reliabel \\
\hline 4 & $\begin{array}{c}\text { Kinerja } \\
\text { Personel }\end{array}$ & 0,761 & Reliabel \\
\hline \multicolumn{3}{|c|}{ Sumber : Data Primer Diolah (2016) } \\
\end{tabular}

\section{Uji Asumsi Klasik}

Uji Normalitas

Sebelum melakukan analisis lebih lanjut untuk mengetahui apakah data penelitian berdistribusi normal, maka terlebih dahulu perlu dilakukan uji normalitas. Pengujian dilakukan dengan menggunakan scatterplot.

Dari pengujian diperoleh hasil sebagaimana tertera pada gambar 2 .

Data Uji Normalitas digunakan untuk mengetahui apakah data yang diperoleh berdistribusi normal atau tidak. Adapun cara yang sering digunakan dalam menentukan apakah suatu model berdistribusi normal atau tidak, hanya dengan melihat pada histogram residual apakah memiliki bentuk seperti lonceng atau tidak. Berdasarkan Gambar 2 tersebut dapat dilihat bahwa data kuesioner memiliki bentuk grafik seperti bentuk lonceng (berdistribusi normal).

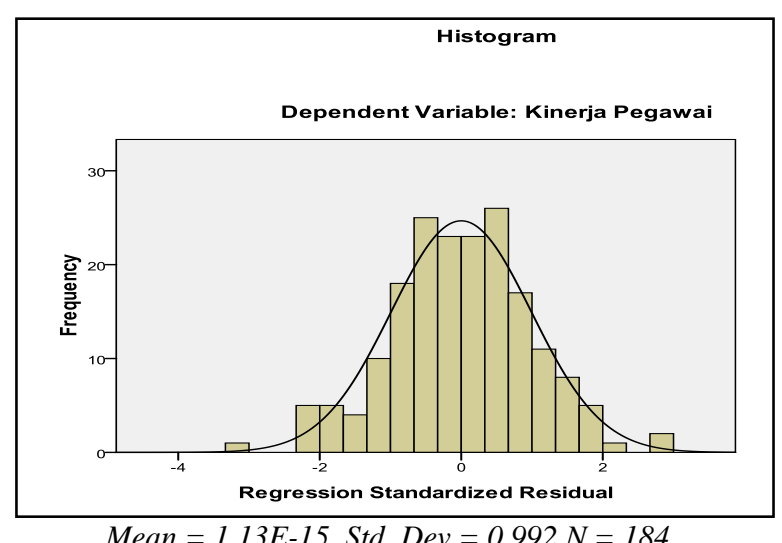

Mean $=1.13 E-15$, Std. Dev $=0.992 N=184$

Gambar 2. Uji Normalitas data

Sumber : Pengolahan data (2016)

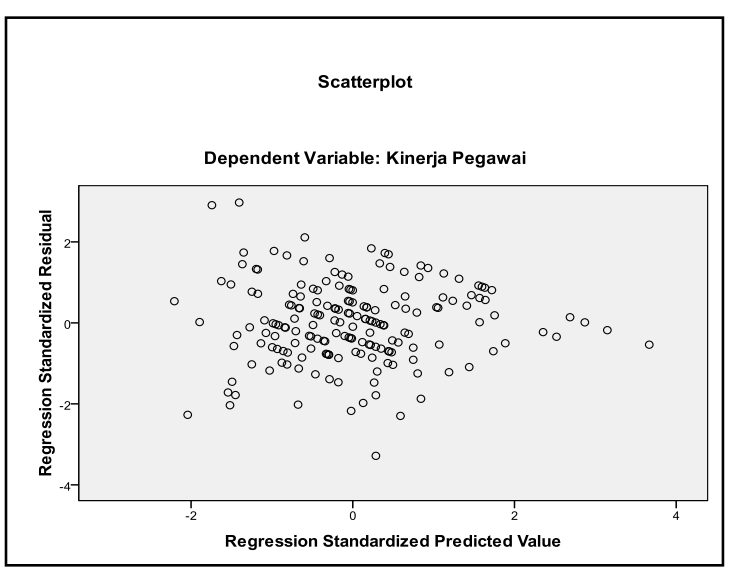

Gambar 3. Uji Heteroskedastisitas

\section{Uji Heteroskedastisitas}

Dari Gambar 3 dapat diketahui bahwa tidak terjadi heteroskedastisitas sebab tidak ada pola yang jelas serta titik-titik menyebar di atas dan di bawah angka 0 pada sumbu Y. Dengan demikian, dapat dikatakan bahwa uji heteroskedastisitas terpenuhi.

\section{Uji Multikolinieritas}

Dari hasil output data didapatkan bahwa semua nilai $\mathbf{V I F}<10$. Hal ini menunjukkan bahwa tidak terjadi multikolonieritas. Atau 
dengan kata lain, dapat disimpulkan bahwa uji

multikolonieritas terpenuhi.

\section{Koefisien Regresi}

Statistik dalam penelitian ini menggambarkan persamaan regresi untuk mengetahui angka konstan dan uji hipotesis signifikansi koefisien regresi.

\section{Regresi Linier Berganda}

Analisis regresi pada dasarnya mempelajari tentang ketergantungan variabel terikat (dependent) dengan satu atau lebih variabel bebas (independent).

Dari hasil uji regresi berganda pada Tabel 5, dapat dibuat persamaan sebagai berikut:

$$
Y=5,535+0,129 X_{1}+0,363 X_{2}+0,342 X_{3}
$$

Dari persamaan regresi yang terbentuk di atas dapat dijelaskan interpretasinya sebagai berikut:

1. $\beta o($ konstanta $)=5,535$ artinya nilai variabel Kinerja Personel (Y) sebesar 5,535 apabila variabel Pelatihan $\left(\mathrm{X}_{1}\right)$, variabel Motivasi kerja $\left(\mathrm{X}_{2}\right)$ dan Kompetensi $\left(\mathrm{X}_{3}\right)$, tidak ada atau sama dengan nol.
Tabel 5. Hasil Uji Regresi Linier Berganda

\begin{tabular}{|c|c|c|c|c|}
\hline \multirow[b]{2}{*}{ Model } & \multicolumn{2}{|c|}{$\begin{array}{l}\text { Unstandardized } \\
\text { Coefficients }\end{array}$} & \multirow[b]{2}{*}{$\mathbf{t}$} & \multirow[b]{2}{*}{ Sig. } \\
\hline & B & $\begin{array}{l}\text { Std. } \\
\text { Error }\end{array}$ & & \\
\hline 1 (Constant) & $\mathbf{5 . 5 3 5}$ & 4.224 & 1.310 & .192 \\
\hline Pelatihan & .129 & .055 & 2.358 & .019 \\
\hline \begin{tabular}{|l} 
Motivasi \\
kerja
\end{tabular} & .363 & .066 & 5.524 & .000 \\
\hline Kompetensi & .342 & .063 & 5.439 & .000 \\
\hline
\end{tabular}

2. $\beta_{1}=0,129$, artinya apabila variabel Pelatihan $\left(\mathrm{X}_{1}\right)$ meningkat dan variabel Motivasi kerja $\left(\mathrm{X}_{2}\right)$ dan Kompetensi $\left(\mathrm{X}_{3}\right)$ tetap maka variabel Kinerja Personel (Y) akan meningkat sebesar 0,129 .

3. $\beta_{2}=0,363$, artinya apabila variabel variabel Motivasi kerja $\left(\mathrm{X}_{2}\right)$ meningkat dan variabel Pelatihan $\left(\mathrm{X}_{1}\right)$ dan Kompetensi $\left(\mathrm{X}_{3}\right)$ tetap maka variabel Kinerja Personel (Y) akan meningkat sebesar 0,363.

4. $\mathrm{B}_{3}=0,342$, artinya apabila variabel variabel Kompetensi $\left(\mathrm{X}_{3}\right)$ meningkat dan variabel Pelatihan $\left(\mathrm{X}_{1}\right)$ dan Motivasi kerja $\left(\mathrm{X}_{2}\right)$ tetap maka variabel Kinerja Personel (Y) akan meningkat sebesar 0,342 .

Berdasarkan data di atas, dapat disimpulkan bahwa Motivasi kerja, mempunyai pengaruh yang paling besar di 
antara variabel penelitian yang lain, dilanjutkan dengan variabel Kompetensi.

\section{Hasil Pengujian Simultan (Uji F)}

Hasil uji signifikan secara simultan dapat dilihat pada Tabel 6. Uji F dilakukan untuk mengetahui pengaruh variabel Pelatihan, Motivasi kerja dan Kompetensi terhadap Kinerja Personel secara simultan. Nilai Sig. sebesar 0.000 menunjukkan untuk tingkat signifikansi alpha sebesar 0.05 two tailed pasti signifikan. Sedangkan untuk pengujian dengan uji $\mathrm{F}$ adalah dengan membandingkan antara nilai $F_{\text {tabel }}$ dengan $F_{\text {hitung. Nilai }} F_{\text {hitung }}$ sebesar 29.225, $\mathrm{F}_{\text {tabel }}$ adalah 2.65 (lihat pada Tabel F), dengan demikian didapat hasil $\mathrm{F}_{\text {hitung }}$ (29.225) > F tabel (2.65) maka Ho ditolak dan $\mathrm{H}_{\mathrm{a}}$ diterima. Dapat disimpulkan bahwa Pelatihan, Motivasi kerja dan Kompetensi secara simultan berpengaruh terhadap Kinerja Personel di Makosek Hanudnas I.

\section{Hasil Pengujian Parsial (Uji t)}

Tabel 7 menjelaskan bahwa kolom Sig. untuk variabel Pelatihan terlihat nilai Significance sebesar 0,019, karena nilai di bawah 0,05 maka dapat dikatakan signifikan. Pengujian dengan menggunakan uji $\mathrm{t}$ adalah, nilai tabel t pada alpha 0.05 (two tail) $\mathrm{df}=\mathrm{n}$ -
Tabel 6. Uji F Simultan

\begin{tabular}{|l|l|r|r|r|r|r|}
\hline \multicolumn{7}{|c|}{ ANOVA } \\
\hline \multirow{2}{*}{ Model } & $\begin{array}{c}\text { Sum of } \\
\text { Squares }\end{array}$ & $\begin{array}{c}\text { Mean } \\
\text { df }\end{array}$ & $\begin{array}{c}\text { Square } \\
\text { F }\end{array}$ & Sig. \\
\hline \multirow{2}{*}{1} & Regression & 979.925 & 3 & 326.642 & 29.225 & $.000^{\mathrm{a}}$ \\
\cline { 2 - 7 } & Residual & 2011.792 & 180 & 11.177 & & \\
\cline { 2 - 7 } & Total & 2991.717 & 183 & & & \\
\hline
\end{tabular}

a. Predictors: (Constant), Kompetensi, Pelatihan, Motivasi kerja

b. Dependent Variable: Kinerja Personel

Sumber : Data Primer Diolah (2016)

$2=184-2=182$ adalah 1.973 . sedangkan nilai $\mathrm{t}$ hitung pada Tabel di atas sebesar uji $\mathrm{t}=$ 2.358. Berarti $t_{\text {hitung }}>t_{\text {tabel }}$ maka Ha diterima dan Ho ditolak, dengan demikian menunjukkan Pelatihan berpengaruh signifikan terhadap Kinerja Personel TNI di Makosek Hanudnas I.

Pada Pelatihan terlihat nilai Significance sebesar 0,000, karena nilai di bawah 0,05 maka dapat dikatakan signifikan. Pengujian dengan menggunakan uji t adalah, nilai tabel $\mathrm{t}$ pada alpha 0.05 (two tail) $\mathrm{df}=\mathrm{n}$ $2=184-2=182$ adalah 1.973 . sedangkan nilai $\mathrm{t}$ hitung pada Tabel diatas sebesar uji $\mathrm{t}=$ 5.524. Berarti $t_{\text {hitung }}>t_{\text {tabel }}$ maka Ha diterima dan Ho ditolak, dengan demikian menunjukkan Motivasi kerja berpengaruh signifikan terhadap Kinerja Personel di Makosek Hanudnas I. 
Pada variabel Kompetensi terlihat nilai Significance sebesar 0,002 , karena nilai di bawah 0,05 maka dapat dikatakan signifikan. Pengujian dengan menggunakan uji t adalah, nilai tabel t pada alpha 0.05 (two tail) $\mathrm{df}=\mathrm{n}$ $2=184-2=182$ adalah 1.973 . sedangkan nilai $\mathrm{t}$ hitung pada Tabel di atas sebesar uji $\mathrm{t}=\mathbf{5 . 4 3 9}$.

Berarti $t_{\text {hitung }}>t_{\text {tabel }}$ sehingga Ha diterima dan Ho ditolak. Atau dengan kata lain, Kompetensi berpengaruh signifikan terhadap Kinerja Personel TNI di Makosek Hanudnas I.

\section{Koefisien Determinasi $\left(\mathbf{R}^{2}\right)$}

Berdasarkan hasil statistik, dapat dikatakan bahwa besarnya $\mathrm{R}$ atau korelasi besarnya variabel independen Pelatihan $\left(\mathrm{X}_{1}\right)$, Motivasi kerja $\left(\mathrm{X}_{2}\right)$ dan Kompetensi $\left(\mathrm{X}_{3}\right)$ secara bersama-sama terhadap variabel dependen Kinerja Personel (Y) adalah sebesar 0.572 dengan tingkat hubungan Sedang. $\mathrm{R}$ square atau koefisen determinan sebesar 0.328 atau $\mathbf{3 2 . 8 \%}$, menunjukkan bahwa Kinerja Personel dipengaruhi ketiga variabel independen yang dipakai dalam penelitian ini (yakni independen Pelatihan $\left(\mathrm{X}_{1}\right)$, Motivasi kerja $\left(\mathrm{X}_{2}\right)$ dan Kompetensi $\left(\mathrm{X}_{3}\right)$ ) sebesar 32.8\%, dan masih ada pengaruh dari faktor lainnya yaitu $67.2 \%$ dari faktor lainnya.
Tabel 7. Matrik Korelasi Antar Dimensi

\begin{tabular}{|c|c|c|c|c|c|c|}
\hline \multirow{2}{*}{$\begin{array}{l}\text { Vari } \\
\text { abel }\end{array}$} & \multirow{2}{*}{ Dimensi } & \multicolumn{5}{|c|}{ Kinerja Personel (Y) } \\
\hline & & $Y_{11}$ & $Y_{12}$ & $Y_{13}$ & $Y_{14}$ & $Y_{15}$ \\
\hline \multirow{12}{*}{ 离 } & Materi & 0.0 & 0.0 & 0.0 & 0.0 & 0.0 \\
\hline & pelatihan & 12 & 68 & 08 & 49 & 36 \\
\hline & Metode & 0.0 & 0.0 & 0.0 & 0.0 & 0.0 \\
\hline & pelatihan & 71 & 25 & 91 & 67 & 48 \\
\hline & Instruktur & 0.1 & 0.0 & 0.0 & 0.0 & 0.0 \\
\hline & Pelatihan & 22 & 96 & 74 & 82 & 50 \\
\hline & Sarana & 0.0 & 0.0 & 0.0 & 0.0 & 0.0 \\
\hline & Pelatihan & 70 & 03 & 45 & 39 & 20 \\
\hline & Peserta & 0.2 & 0.0 & 0.4 & 0.1 & 0.0 \\
\hline & Pelatihan & 83 & 51 & 95 & 63 & 05 \\
\hline & Evaluasi & 0.2 & 0.0 & 0.0 & 0.3 & 0.2 \\
\hline & Pelatihan & 26 & 87 & 55 & 23 & 16 \\
\hline \multirow{6}{*}{ 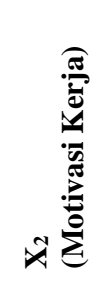 } & Faktor & & & & & 0.0 \\
\hline & Instrinsik & 0.1 & 0.1 & 0.2 & 0.0 & 78 \\
\hline & $\begin{array}{l}\text { (Faktor } \\
\text { Internal) }\end{array}$ & 16 & 15 & 07 & 28 & \\
\hline & Faktor & & & & & 0.2 \\
\hline & Ekstrinsik & 0.2 & 0.2 & 0.3 & 0.4 & 96 \\
\hline & $\begin{array}{l}\text { (Faktor } \\
\text { Eksternal) }\end{array}$ & 96 & 03 & 64 & 28 & \\
\hline \multirow{12}{*}{ 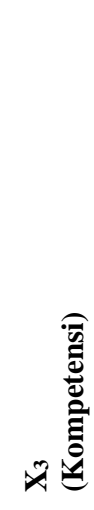 } & Pengetahuan & 0.3 & 0.1 & 0.2 & 0.2 & 0.1 \\
\hline & (Knowledge) & 07 & 58 & 50 & 62 & 89 \\
\hline & Pemahaman & 0.0 & 0.1 & 0.1 & 0.1 & 0.1 \\
\hline & (Understanding & 97 & 60 & 34 & 27 & 77 \\
\hline & Kemampuan/K & 0.0 & 0.2 & 0.0 & 0.1 & 0.2 \\
\hline & $\begin{array}{l}\text { etrampilan } \\
\text { (Skill) }\end{array}$ & 18 & 95 & 41 & 69 & 05 \\
\hline & Nilai (Value) & 0.1 & 0.1 & 0.2 & 0.1 & 0.1 \\
\hline & & 75 & 47 & 84 & 47 & 12 \\
\hline & Sikap (Attitude) & 0.0 & 0.0 & 0.0 & 0.1 & 0.0 \\
\hline & & 50 & 94 & 89 & 57 & 76 \\
\hline & Minat (Interest) & 0.3 & 0.4 & 0.2 & 0.2 & 0.0 \\
\hline & & 38 & 44 & 32 & 16 & 94 \\
\hline
\end{tabular}

Sumber : Data Primer Diolah (2016)

\section{Pengujian Korelasi antar Dimensi}

Matrik korelasi antar dimensi dependen dengan independen digunakan untuk meneliti pengaruh mana yang paling kuat untuk dimensi dari variabel independen terhadap variabel dependen.

Secara terperinci dapat dijabarkan pada Tabel 7 yang menunjukkan bahwa:

1. Untuk Variabel Pelatihan, dimensi yang paling kuat hubungannya adalah dimensi Peserta Pelatihan terhadap 
Tabel 8. Pedoman Untuk Memberikan Interpretasi Koefisien Korelasi

\begin{tabular}{|c|c|}
\hline Interval Koefisien & $\begin{array}{c}\text { Tingkat } \\
\text { Hubungan }\end{array}$ \\
\hline $0,00-0,199$ & Sangat Rendah \\
\hline $0,20-0,399$ & Rendah \\
\hline $0,40-0,599$ & Sedang \\
\hline $0,60-0,799$ & Kuat \\
\hline $0,80-1,000$ & Sangat Kuat \\
\hline \multicolumn{2}{|c|}{ Sumber : Sugiyono (2009:287) } \\
\hline
\end{tabular}

dimensi Pemanfaatan Waktu pada

Kinerja Personel, karena memiliki nilai koefisien $=0.495$ (memiliki tingkat hubungan yang "Sedang").

2. Untuk Variabel Motivasi kerja, dimensi yang paling kuat hubungannya adalah dimensi Faktor Ekstrinsik (Faktor Eksternal) terhadap dimensi Kehadiran pada Kinerja Personel, karena memiliki nilai koefisien $=\mathbf{0 . 4 2 8}($ memiliki tingkat hubungan yang "Sedang")

3. Untuk Variabel Kompetensi, dimensi yang paling kuat hubungannya adalah dimensi Minat (Interest) terhadap dimensi Kualitas pekerjaan pada Kinerja Personel, karena memiliki nilai koefisien $=0.444$ (memiliki tingkat hubungan yang "Sedang")

\section{KESIMPULAN DAN SARAN}

Dari serangkaian penelitian yang telah dilaksanakan maka disimpulkan:
1. Pelatihan berpengaruh positif dan signifikan terhadap Kinerja Personel di Makosek Hanudnas I. Artinya, jika Pelatihan baik maka kinerja Personel baik. Dimensi Pelatihan yang paling kuat hubungannya adalah dimensi Peserta Pelatihan terhadap dimensi Pemanfaatan Waktu pada Kinerja Personel.

2. Motivasi kerja berpengaruh positif dan signifikan terhadap Kinerja Personel di Makosek Hanudnas I. Artinya, jika motivasi meningkat maka kinerja Personel juga akan meningkat. Dimensi motivasi kerja yang paling kuat hubungannya dimensi Faktor Ekstrinsik (Faktor Eksternal) terhadap dimensi Kehadiran pada Kinerja Personel.

3. Kompetensi berpengaruh positif dan signifikan terhadap Kinerja Personel militer/TNI di Makosek Hanudnas I. Artinya, jika para personel memiliki Kompetensi yang baik maka kinerja Personel juga akan meningkat. Dimensi Kompetensi yang paling kuat hubungannya adalah dimensi Minat (Interest) terhadap dimensi Kualitas Pekerjaan pada Kinerja Personel. 
4. Pelatihan, Motivasi kerja dan Kompetensi secara bersama-sama berpangaruh positif dan signifikan terhadap Kinerja Personel. Artinya, jika Kompetensi, Motivasi kerja dan Pelatihan berjalan dengan baik, maka akan meningkatkan Kinerja Personel. Besarnya $\mathrm{R}$ atau korelasi variabel independen Pelatihan, Motivasi kerja dan Kompetensi secara bersama-sama berpengaruh terhadap variabel dependen Kinerja Personel sebesar 0.572 dengan tingkat hubungan Sedang. Kinerja Personel dipengaruhi ketiga variabel independen yang dipakai dalam penelitian ini yakni Pelatihan, Motivasi kerja dan Kompetensi sebesar 32.8\%, dan masih ada pengaruh dari faktor lainnya yaitu sebesar $67.2 \%$ 
Pengaruh Pelatihan, Motivasi Kerja dan Kompetensi....(A. Badawi, Tersia M, \& Bambang M)

\section{DAFTAR PUSTAKA}

Arikunto, S. 2012. Prosedur Penelitian: Suatu Pendekatan Praktek. Jakarta: Rineka Cipta.

Chapman, A. 2006. Peter, J. Paul \& Olson, C. Jerry. 2005. Consumer Behaviour \& Marketing Strategy. McGraw-Hill Companies, Inc., 1221 Avenue of the Americas, New York, NY

Depdiknas, 2008, “Kamus Besar Bahasa Indonesia”, Gramedia Pustaka Indonesia.

Dessler, Gary, 2009. Manajemen Sumber Daya Manusia. Jakarta: Indeks.

Dessler, Gary. 2003. Human Resource Management Tenth Edition. New Jersey: Prentice Hall

Efendi Hariandja, Marihot Tua.2002. Manajemen Sumber Daya Manusia (Pengadaan, Pengembangan, Kompensasi, Peningkatan Pegawai), Jakarta: Gramedia.

Fahmi, Irham. 2010. “Manajemen Kinerja Teori dan Aplikasi”, Bandung : Alfabeta.

Fakhrika andalusi, 2014.'Pengaruh Tingkat Pendidikan dan Pengalaman Mengajar terhadap Kompetensi Pedagogik Guru di SMK Muhammadiyah Delanggu. Surakarta

Gaol, CHR. Jimmy L, 2014. A to Z Human Capital (Manajemen Sumber Daya Manusia) Konsep, Teori, dan Pengembangan dalam Konteks Organisasi Publik dan Bisnis, PT. Gramedia Widiasarana, Jakarta.

Ghozali, Imam. (2011). Aplikasi Analisis Multivariat dengan Program SPSS. Badan Penerbit Universitas Diponegoro, Semarang.

Green, Lawrence W., Marchel W Kreuter. 2005. Health Promoting Planning an educational and environmental aproach. Second Edition. Mayfield Publishing Company: Mountain View.

Gujarati, Damodar. (Elmasari, 2010). Dasar-Dasar Ekonometrika. Jakarta: Erlangga.

Handoko TH,. 2001. Manajemen Personalia dan Sumber Daya Manusia. Edisi 2. Yogyakarta: BPFE Hasibuan, Malayu S.P., 2011. Manajemen Sumber Daya Manusia. Bumi Aksara, Jakarta.

Hasibuan, Malayu S.P, 2006. Manajemen Dasar, Pengertian, dan Masalah,Edisi Revisi, Bumi Aksara:Jakarta Husaini, Usman. 2010. Manajemen: teori,praktik dan riset pendidikan Edisi 3, Cetakan 1.Jakarta: Bumi Aksara.

Husein Umar. 2005. Evaluasi Kinerja Perusahaan. Jakarta : Gramedia Pustaka Utama 
Lembaga Administrasi Negara (LAN) RI. 2008. Badan Pengawasan Keuangan dan Pembangunan (BPKP), Pengukuran Kinerja Instansi Pemerintah: Modul Sosialisasi Sistem Akuntabilitas Kinerja Istitut Pemerintah. Lembaga Administrasi Negar (LAN) RI.

Mahmudi. 2007. Manajemen Kinerja Sektor Publik, UPP STIM YKPN, Yogyakarta.

Malhotra, N.K., 2009. Riset Pemasaran, Edisi keempat, Jilid 1, PT Indeks, Jakarta.

Mangkuprawira Syafri, 2003. Manajemen Sumber Daya Manusia Strategik. Ghalia Indonesia, Jakarta. Mathis, dan Jackson, 2002. Manajemen Sumber Daya Manusia, Edisi pertama, Cetakan Pertama, Yogyakarta : Salemba Empat.

Mitchell dalam Sedarmayanti (2005). Sumber Daya Manusia dan Produktivitas Kerja. Bandung : CV. Mandar Maju.

Mulyasa, E. 2007. Standar Kompetensi Dan Sertifikasi Guru. Bandung: PT.Remaja Rosdakarya.

Ngalim, Purwanto, 2006. Psikologi Pendidikan. Bandung: Remaja Rosdakarya.

Nugroho B.A. 2005. Strategi Jitu Memilih Metode Statistik Penelitian dengan SPSS. Yogyakarta: Penerbit ANDI

Palan, R. 2008. Competency Management. Cetakan kedua. PPM, Jakarta Pusat

Priyatno, Dwi, 2008. Mandiri Belajar SPSS untuk Analisis Data dan Uji Statistik, Edisi Pertama, Mediakom, Jakarta

Ronny Kountur,D.M.S., (2005). Metode Penelitian Untuk Penulisan skripsi dan Tesis. Cetakan ketiga. PPM. Jakarta.

Sedarmayanti. 2011. Tata Kerja dan Produktivitas Kerja : Suatu Tinjauan Dari Aspek Ergonomi Atau Kaitan Antara Manusia Dengan Lingkungan Kerjanya. Cetakan Ketiga. Bandung: Mandar Maju Siagian P. Sondang. 2008. Manajemen SDM. Cet 16. Jakarta : Bumi Aksara.

Siagian P. Sondang. 2004. Kiat Meningkatkan Produktivitas Kerja. Jakarta : Rineka Cipta.

Siagian P. Sondang. 2002. Manajemen Sumber Daya Manusia. Jakarta: PT Bumi Aksara.

Simanjuntak, Payaman J. 2005. Manajemen dan Evaluasi Kinerja. Jakarta: FE UI.

Singarimbun, Masri.2006. Metode Penelitian Survay .LP3ES: Jakarta.

Stoner, J.A.F., Freeman, R.E., dan Gilbert, D.R. 1992. Management Edisi ke-13. New Jersey : Prentice Hall 
Pengaruh Pelatihan, Motivasi Kerja dan Kompetensi....(A. Badawi, Tersia M, \& Bambang M)

Sudarmanto, R.Gunawan. (2005). Analisis Regresi Linear Ganda dengan SPSS. Graha Ilmu. Yogyakarta.

Sugiyono. 2011. Metode Penelitian Kuantitatif kualitatif dan R\&D. Bandung: Alfabeta

Suryabrata, Sumadi. 2005. Pengembangan Alat Ukur Psikologis. Yogyakarta: Andi.

Sutrisno, Edy. 2011. Manajemen Sumber Daya Manusia. Jakarta: Kencana.

Tika, Pabundu, 2006. Budaya Organisasi dan Peningkatan Kinerja Perusahaan, Bumi Aksara, Jakarta.

Veithzal Rivai. \& Sagala Jauvani. 2010. Manajemen Sumber Daya Manusia Untuk Perusahaan (2th ed) Jakarta : Rajawali Pers

Veithzal Rivai. (2005). Kepemimpinan dan Perilaku Organisasi, PT. Raja Grafindo Persada, Jakarta.

Veithzal Rivai. 2004. Manajemen Sumber Daya Manusia Untuk Perusahaan : Dari Teori Ke Praktik.

PT. Raja Grafindo Persada, Jakarta.

Wibowo. 2009. Manajemen Kinerja. Jakarta : Rajawali Pres

Wirawan. 2009. Evaluasi Kinerja Sumber Daya Manusia Teori Aplikasi dan Penelitian. Jakarta. 